\title{
Evaluation of Turmeric Variety Salem with Different Rhizome Types and Population Levels on Raised Beds
}

\author{
Preetham $^{1 *}$, Ashwini ${ }^{2}$, Pavan $^{3}$ and Ravi Kondle ${ }^{4}$ \\ ${ }^{1}$ Horticultural Research Station (SKLTSHU), Adilabad, Telangana state-504 001, India \\ ${ }^{2}$ Horticultural Research Station, Adilabad, India \\ ${ }^{3} \mathrm{KVK}$, Adilabad, India \\ ${ }^{4} U B K V$, West Bengal, India \\ *Corresponding author
}

Keywords

Turmeric, Plant

population levels,

Rhizome types, Growth,

Yield attributes and Yield

Article Info

Accepted:

26 March 2018

Available Online:

10 April 2018
A B S T R A C T

A field experiment was conducted at Horticultural Research Station, Adilabad (Northern Telangana Zone) of Telangana state for two consecutive years 2016 and 2017 to find out the performance of Salem variety of turmeric with two planting materials (Split and full rhizome) and three population levels $\left(1,48,148,74,074\right.$ and 98,765 plants $\left.\mathrm{ha}^{-1}\right)$ on raised beds. The two years study revealed that full rhizomes used as planting material showed significantly higher mean plant height of $34.20,58.47,80.61$ and $82.68 \mathrm{~cm}$ at $60,90,120$ and 150 DAP respectively. Full rhizome treatment showed significantly higher number of mother rhizomes (3.86), primary fingers (12.54), secondary fingers plant ${ }^{-1}(15.98)$, clump weight plant ${ }^{-1}(1035 \mathrm{~g})$, girth of mother rhizome $(19.13 \mathrm{~cm})$, weight of mother rhizome $(86.18 \mathrm{~g})$ and fresh rhizome yield $\left(21.58 \mathrm{t} \mathrm{ha}^{-1}\right)$ over split rhizome treatment. Plant population densities did not differ significantly for plant height and number of leaves plant $^{-1}$ during all growth stages during both the years of study. Maximum number of mother rhizomes (3.97), primary fingers (13.05), secondary fingers (16.94), clump weight plant $^{-1}(1140 \mathrm{~g})$, girth of mother rhizome $(21.60 \mathrm{~cm})$ and weight of mother rhizome $(87.65$ g) were recorded in 74,074 plant population treatment. Maximum fresh rhizome yield $\left(20.14 \mathrm{t} \mathrm{ha}^{-1}\right)$ was recorded with plant population stand of $1,48,148$ plants ha ${ }^{-1}$ which was on par with plant population stand of 98,765 and 74,074 plants ha $^{-1}$.

\section{Introduction}

Turmeric (Curcuma longa $\mathrm{L}$ ) is an ancient and sacred spice of India known as 'Indian saffron' is an important commercial spice crop grown in India. Turmeric is extensively used as a stimulant, blood purifier, carminative tonic as well as remedy against the skin diseases, itches, pain and is anti-helminthic
(Srimal, 1997). It possesses anti cancerous properties (Kuttan et al., 1985) and is also considered to cure AIDS (Cohly et al., 2003).

Due to its anti-oxidant properties, controls Alzheimer's disease in human beings (Risch, 1997). In addition to this, it possesses antiviral properties and hence, finds use in the drug industry and cosmetic industry. 
The world production of turmeric stands around 8 lakh tonnes, of which the contribution of India is approximately 75-80 per cent. India is the largest producer, consumer and exporter of turmeric in the world. Turmeric is cultivated throughout India covering an area of 2.08 lakh hectares with an annual production of 1029 million tonnes and productivity of 5.1 metric tonnes per hectare (National Horticultural Board, 2014). In India, Telangana, Andhra Pradesh and Tamil Nadu are the leading turmeric growing states. Turmeric is an important spice crop in Telangana and it ranks second in production after Tamilnadu state and is grown in the districts of Karimnagar, Warangal, Nizamabad and Adilabad with a total area of 56,432 hectares with production of 3,05,824 tonnes (Department of Horticulture, Govt. of Telangana 2016-17 advance estimates).

For higher productivity of turmeric, identification of location specific production technologies like suitable planting methods and optimum plant population are of prime importance. Optimum plant stand of a crop varies considerably depending upon the climatic conditions of the growing area and fertility status of the soil. Plant to plant distance is an important factor for higher production and gives equal opportunity to the plants for their survival and best use of inputs. The full yield potential of an individual plant is achieved at wider spacing, where-as yield per unit area is higher, when the individual plants are subjected to severe competition (Holliday, 1960). Spacing is one of the factors, which greatly influences the yield contributing characters and eventually affects the yield of turmeric to a greater extent (Aiyadural, 1966; Purseglove et al., 1981).

The broad bed and furrow system consists of semi-permanent broad beds of approximately $100 \mathrm{~cm}$ wide, separated by furrow of about 50 $\mathrm{cm}$ wide and $15 \mathrm{~cm}$ deep with a rolling slope of $0.4-0.7 \%$ for safe drainage of excess water; crops can be grown on these beds in 2-4 rows. This system is a good option for cultivating crops in waterlogged areas; beneficial for high productivity, improved drainage, and also for in-situ moisture conservation. There was a yield advantage of 11-18\% in Broad bed and furrow system compared to that of flat-bed system in the field demonstration. (IISS Publication: Two Decades of Soil Research, 2009).

Turmeric is propagated by vegetative methods using mother as well as finger rhizomes. The type and weight of planting material used affects the vigour of the plant and crop yield per unit area as well as the cost of production (Philip, 1985). Randhawa and Mishra (1974) while studying the effect of seed size in turmeric reported that large sized rhizome weighing approximately $100 \mathrm{~g}$ gave significantly higher yield $\left(61 \mathrm{q} \mathrm{ha}^{-1}\right)$ than small sized rhizomes $\left(53.3 \mathrm{q} \mathrm{ha}^{-1}\right)$ of $50 \mathrm{~g}$ weight. While some workers obtained optimum yield from the use of mother rhizome as planting material (Meenakshi et al., 2001) others either reported optimum crop yield from finger rhizome (Chandra et al., 1997; Maia et al., 1995) or no significant yield difference in the type of seed materials used (Govinden Maia et al., 1995). Seed quantity and the cost on seed also can be reduced by utilizing split rhizomes, if split rhizomes show on par yields to full rhizomes.

Hence, an experiment was set up to ascertain the performance of turmeric with different population levels and rhizome types on raised beds at Horticultural Research Station, Adilabad which falls in Northern Telangana Zone of Telangana state.

\section{Materials and Methods}

A field experiment was conducted at Horticultural Research Station, Adilabad during kharif seasons of 2016 and 2017. The experimental site is located in Northern 
Telanagana zone of Telangana State at an altitude of 264 meters above mean sea level on $79^{\circ} 56^{\prime} 03$ " E longitude and $19^{\circ} 08^{\prime} 09^{\prime \prime} \mathrm{N}$ latitude. The soil is sandy clay loam texture, slightly acidic, low in nitrogen, medium in phosphorous and high in potassium content. The experiment was laid out in factorial randomized block design (FRBD) replicated four times.

The experimental field was ploughed twice with disc plough followed by ploughing with a cultivator and two planking's were done for the preparation of field to obtain good tilth. Well decomposed FYM @ $30 \mathrm{t} \mathrm{ha}^{-1}$ and 500 $\mathrm{kg} \mathrm{ha}^{-1}$ of neem cake was thoroughly mixed into the soil at the time of bed preparation. A basal dose of $60 \mathrm{~kg} \mathrm{ha}^{-1}$ each of phosphorous (375 kg SSP) and potash (100 kg MOP) were uniformly broadcasted in the experimental field before last planking. Semi-permanent broad beds of approximately $100 \mathrm{~cm}$ wide, separated by furrow of about $50 \mathrm{~cm}$ wide and $15 \mathrm{~cm}$ deep with a rolling slope of 0.4-0.7\% were made with bed maker.

Salem a popular cultivar of Tamil Nadu rich in curcumin content which is successfully grown in and around Adilabad was selected for evaluation. Seed material was obtained from Turmeric Research Station, Kammarpally. The variety was evaluated for different population levels and rhizome types on raised beds. Treatments comprised of 2 rhizome types: split and full rhizome and 3 spacing's of $30 \mathrm{x}$ $15 \mathrm{~cm}, 30 \times 30 \mathrm{~cm}$ and $45 \times 15 \mathrm{~cm}$ (Plant stand of 1,48,148, 74,074 and 98,765 plants $\left.\mathrm{ha}^{-1}\right)$. The seed material was treated with ridomil@3g and malathion@3 ml per litre. First irrigation was given immediately after planting and there after irrigations was given at weekly intervals depending upon the soil moisture conditions. The pre-emergence herbicide Pendimethalin 30 EC @ $7.5 \mathrm{ml}$ per litre of water was sprayed immediately after planting. First weeding was done at 30 days after planting. There-after, weeding was done regularly depending upon the weed intensity and plots were kept weed free throughout the crop growth period. $500 \mathrm{~kg}$ neem cake, $125 \mathrm{~kg}$ urea and $50 \mathrm{~kg}$ MOP ha ${ }^{-1}$ were applied at 40 and 120 DAP as top dressing. Need based plant protection measures were taken up to keep the experimental plot free from pest and diseases to raise a healthy crop.

Five plants in each treatment per replication were tagged randomly for recording of observations on growth, yield attributes and yield. Plant height was recorded from base of the plant to the tip of the new fully opened leaf at 60, 90, 120, and 150 DAP from tagged plants in each plot and expressed as average height of five plants in $\mathrm{cm}$. The number of fully opened leaves at 60,90, 120, and 150 DAP were counted and the mean value of five plants were calculated and expressed in number of leaves per plant. The data on the yield parameters like weight of clump, weight of mother rhizomes, girth of mother rhizome and number of mother rhizomes, number of primary and secondary fingers per plant were recorded from five plants tagged in each plot at harvest and the average was worked out. Data collected was subjected to ANOVA for factorial RBD.

\section{Results and Discussion}

\section{Growth parameters}

\section{Plant height $(\mathrm{cm})$}

The rhizome types (Full and split) differed significantly for plant height at various growth stages of turmeric during both the years of study. The data on plant height revealed that a mean plant height of $34.20 \mathrm{~cm}, 58.47 \mathrm{~cm}$, $80.61 \mathrm{~cm}$ and $82.68 \mathrm{~cm}$ was recorded at 60 , 90, 120 and 150 DAP respectively when full rhizome was used as planting material as against $31.03 \mathrm{~cm}, 53.00 \mathrm{~cm}, 73.71 \mathrm{~cm}$ and 
$77.43 \mathrm{~cm}$ at 60, 90, 120 and 150 DAP respectively with split rhizome (Table 1). These results are in agreement with the following findings (Yothasiri et al., 1997; Jage Singh et al., 2000; Meenakshi et al., 2001; Hanamashetti et al., 2002; Alam et al., 2003; Amzad Hossain et al., 2005; Joe et al., 2007; Ram pratap and Singh, 2007; Dhatt et al., 2008; Girma and Kindie, 2008; Olejede et al., 2009; Balwinderkumar and Gill, 2010; Manhas et al., 2011; Padmadevi et al., 2012; Singh et al., 2013 and Shiferaw et al., 2017). The usage of full rhizomes have given the best performance, this might be due to significant food reserves which helped for vigorous plant height. Maximum mean plant height of 33.22 $\mathrm{cm}, 57.34 \mathrm{~cm}, 80.22 \mathrm{~cm}$ and $81.86 \mathrm{~cm}$ was recorded at 60, 90, 120 and 150 DAP with a plant population of $74,074 \mathrm{ha}^{-1}$, but the different plant population densities $(1,48,148$, 74,074 and 98,765 $\mathrm{ha}^{-1}$ ) had no significant effect on plant height during both the years of study. Similar type of results was observed by Kiran et al., (2013) and Hossain et al., (2005). Intra row shading and competition for light and space might be the reason for low plant height at high population densities.

\section{Number of leaves plant ${ }^{-1}$}

Full rhizome treatment recorded significantly higher number of leaves $(11.16,15.40$ and 15.72) over split rhizome treatment (10.03, 13.40 and 13.73) at 90, 120 and 150 DAP respectively in 2016. These results are in accordance with the findings of Meenakshi et al., (2001), Hanamashetti et al., (2002), Alam et al., (2003), Amzad Hossain et al., (2005), Ram pratap and Sing (2007), Dhatt et al., (2008), Girma and Kindie (2008), Balwinderkumar and Gill (2010), Manhas et al., (2011), Padmadevi et al., (2012) and Singh et al., (2013). There was no significant difference for number of leaves plant ${ }^{-1}$ for different plant population densities of 1,48,148, 74,074 and 98,765 $\mathrm{ha}^{-1}$, however maximum mean number of leaves plant $^{-1}$
(4.59, 9.21, 12.19 and 12.90) at 60, 90, 120 and 150 DAP respectively were recorded in the treatment with a plant population stand of 74,074 plants per ha $^{-1}$. Similar results were reported by Bahadur et al., (2000), Islam et al., (2002), Manjunathgoud et al., (2002), Pandey et al., (2011) and Kiran et al., (2013). Wider spacing of $30 \times 30 \mathrm{~cm}$ with a plant stand 74,074 ha $^{-1}$ gave an opportunity for more availability of nutrients, moisture and better interception of light for development of more number of leaves.

\section{Yield attributes and Yield}

\section{Number of mother rhizomes, primary and secondary fingers per plant}

Significant difference was observed among the various treatments for number of mother rhizomes, primary and secondary fingers plant $^{-1}$ during both the years of study. Full rhizome treatment produced 3.86, 12.54 and 15.98 mother rhizomes, primary fingers and secondary fingers plant $^{-1}$ respectively (mean of two years) as against the split rhizome treatment which produced 3.39, 11.16 and 14.26 mother rhizomes, primary fingers and secondary fingers plant ${ }^{-1}$. Similar results were reported by Dhatt et al., (2008), Olojede et al., (2009), Balwinder and Gill (2010), Manhas and Gill (2012), Singh et al., (2013) and Shiferaw et al., (2017). Plant population stand showed significant effect on the production of number of mother rhizomes, primary fingers and secondary fingers plant $^{-1}$. A plant population stand of $74,074 \mathrm{ha}^{-1}$ recorded maximum number of mother rhizomes (3.75 and 4.18), primary fingers (13.50 and 12.59) and secondary fingers (16.88 and 17.00) during 2016 and 2017 respectively (Table 3). Wider spacing might have given the plants an opportunity to utilize more space and resources for the production of more number of mother rhizomes, primary fingers and secondary fingers plant ${ }^{-1}$ (Table 2). 
Table.1 Effect of different rhizome types and plant population levels on periodic plant height of turmeric during 2016 and 2017

\begin{tabular}{|c|c|c|c|c|c|c|c|c|c|c|c|c|}
\hline \multirow[t]{3}{*}{ Treatment } & \multicolumn{12}{|c|}{ Plant Height (cm) } \\
\hline & \multicolumn{3}{|c|}{60 DAP } & \multicolumn{3}{|c|}{90 DAP } & \multicolumn{3}{|c|}{120 DAP } & \multicolumn{3}{|c|}{150 DAP } \\
\hline & 2016 & 2017 & Mean & 2016 & 2017 & Mean & 2016 & 2017 & Mean & 2016 & 2017 & Mean \\
\hline \multicolumn{13}{|l|}{ Rhizome type } \\
\hline Split Rhizome & 37.16 & 24.89 & 31.03 & 63.38 & 42.61 & 53.00 & 80.36 & 67.06 & 73.71 & 83.32 & 71.53 & 77.43 \\
\hline Full Rhizome & 41.07 & 27.33 & 34.20 & 69.74 & 47.20 & 58.47 & 86.25 & 74.97 & 80.61 & 89.42 & 75.93 & 82.68 \\
\hline$C D(p=0.05)$ & 2.72 & 1.31 & & 4.67 & 3.15 & & 4.52 & 4.17 & & 4.59 & 1.16 & \\
\hline \multicolumn{13}{|c|}{ Plant Population ha ${ }^{-1}$} \\
\hline $1,48,148$ & 38.64 & 25.60 & 32.12 & 66.25 & 43.66 & 54.96 & 81.73 & 69.00 & 75.37 & 85.59 & 73.31 & 79.45 \\
\hline 74,074 & 39.78 & 26.66 & 33.22 & 67.30 & 47.38 & 57.34 & 86.36 & 74.08 & 80.22 & 89.21 & 74.51 & 81.86 \\
\hline 98,765 & 38.93 & 26.03 & 32.48 & 66.13 & 43.68 & 54.91 & 81.83 & 69.96 & 75.90 & 84.30 & 73.35 & 78.83 \\
\hline $\mathrm{CD}(\mathrm{p}=0.05)$ & NS & NS & & NS & NS & & NS & NS & & NS & NS & \\
\hline
\end{tabular}

All interactions: Non significant

Table.2 Effect of different rhizome types and plant population levels on number of leaves per plant periodically during 2016 and 2017

\begin{tabular}{|c|c|c|c|c|c|c|c|c|c|c|c|c|}
\hline \multirow[t]{3}{*}{ Treatment } & \multicolumn{12}{|c|}{ Number of leaves plant ${ }^{-1}$} \\
\hline & \multicolumn{3}{|c|}{60 DAP } & \multicolumn{3}{|c|}{90 DAP } & \multicolumn{3}{|c|}{$120 \mathrm{DAP}$} & \multicolumn{3}{|c|}{150 DAP } \\
\hline & 2016 & 2017 & Mean & 2016 & 2017 & Mean & 2016 & 2017 & Mean & 2016 & 2017 & Mean \\
\hline \multicolumn{13}{|l|}{ Rhizome type } \\
\hline Full Rhizome & 4.95 & 3.98 & 4.47 & 11.16 & 7.18 & 9.17 & 15.40 & 8.98 & 12.19 & 15.72 & 9.97 & 12.85 \\
\hline $\mathrm{CD}(\mathrm{p}=0.05)$ & NS & NS & & 0.70 & NS & & 1.44 & NS & & 1.40 & NS & \\
\hline 74,074 & 5.05 & 4.13 & 4.59 & 11.11 & 7.30 & 9.21 & 15.23 & 9.15 & 12.19 & 15.60 & 10.20 & 12.90 \\
\hline 98,765 & 4.75 & 3.90 & 4.33 & 10.53 & 7.10 & 8.82 & 14.58 & 8.78 & 11.68 & 14.90 & 9.95 & 12.43 \\
\hline $\mathrm{CD}(\mathrm{p}=0.05)$ & NS & NS & & NS & NS & & NS & NS & & NS & NS & \\
\hline
\end{tabular}

All interactions: Non-significant 
Table.3 Effect of different rhizome types and plant population levels on number of rhizomes or fingers plant ${ }^{-1}$ in turmeric during 2016 and 2017

\begin{tabular}{|c|c|c|c|c|c|c|c|c|c|c|c|c|}
\hline \multirow[t]{3}{*}{ Treatment } & \multicolumn{12}{|c|}{ Number of Rhizomes or fingers plant ${ }^{-1}$} \\
\hline & \multicolumn{3}{|c|}{ Mother Rhizomes } & \multicolumn{3}{|c|}{ Primary fingers } & \multicolumn{3}{|c|}{ Secondary fingers } & \multicolumn{3}{|c|}{ Total } \\
\hline & 2016 & 2017 & Mean & 2016 & 2017 & Mean & 2016 & 2017 & Mean & 2016 & 2017 & Mean \\
\hline \multicolumn{13}{|l|}{ Rhizome type } \\
\hline Full Rhizome & 3.67 & 4.05 & 3.86 & 13.00 & 12.08 & 12.54 & 15.75 & 16.20 & 15.98 & 29.67 & 32.42 & 31.05 \\
\hline $\mathrm{CD}(\mathrm{p}=0.05)$ & 0.38 & 0.27 & & 1.37 & 0.79 & & 0.99 & 1.56 & & & & \\
\hline 74,074 & 3.75 & 4.18 & 3.97 & 13.50 & 12.59 & 13.05 & 16.88 & 17.00 & 16.94 & 30.13 & 33.27 & 31.70 \\
\hline 98,765 & 3.50 & 3.68 & 3.59 & 12.25 & 11.53 & 11.89 & 15.00 & 15.43 & 15.22 & 28.63 & 30.64 & 29.64 \\
\hline $\mathrm{CD}(\mathrm{p}=0.05)$ & 0.46 & 0.33 & & 1.68 & 0.97 & & 1.21 & 1.91 & & & & \\
\hline
\end{tabular}

All interactions: Non significant

Table.4 Effect of different rhizome types and plant population levels on yield attributes and yield of turmeric during 2016 and 2017

\begin{tabular}{|c|c|c|c|c|c|c|c|c|c|c|c|c|c|c|c|}
\hline \multirow[t]{2}{*}{ Treatment } & \multicolumn{3}{|c|}{$\begin{array}{l}\text { Clump Weight } \\
\left(\text { gplant }^{-1}\right)\end{array}$} & \multicolumn{3}{|c|}{$\begin{array}{l}\text { Girth of Mother } \\
\text { Rhizome (cm) }\end{array}$} & \multicolumn{3}{|c|}{$\begin{array}{l}\text { Weight of Mother } \\
\text { rhizome (g) }\end{array}$} & \multicolumn{3}{|c|}{$\begin{array}{c}\text { Fresh rhizome yield } \\
\text { per plot (kg) }\end{array}$} & \multicolumn{3}{|c|}{$\begin{array}{l}\text { Fresh rhizome } \\
\text { yield }\left(\mathbf{t ~ h a}^{-1}\right)\end{array}$} \\
\hline & 2016 & 2017 & Mean & 2016 & 2017 & Mean & 2016 & 2017 & Mean & 2016 & 2017 & Mean & 2016 & 2017 & Mean \\
\hline \multicolumn{16}{|l|}{ Rhizome type } \\
\hline Full Rhizome & 1060 & 1010 & 1035 & 20.10 & 18.15 & 19.13 & 82.33 & 90.02 & 86.18 & 36.15 & 28.57 & 32.36 & 24.10 & 19.05 & 21.58 \\
\hline$C D(p=0.05)$ & 87 & 66 & & 1.46 & 0.83 & & 6.91 & 4.45 & & 1.19 & 2.65 & & 0.79 & 1.77 & \\
\hline 74,074 & 1165 & 1115 & 1140 & 24.42 & 18.78 & 21.60 & 81.75 & 93.55 & 87.65 & 32.77 & 24.38 & 28.58 & 21.85 & 16.25 & 19.05 \\
\hline 98,765 & 858 & 967 & 912.5 & 17.34 & 17.55 & 17.45 & 75.38 & 87.86 & 81.62 & 33.29 & 24.91 & 29.10 & 22.19 & 16.61 & 19.40 \\
\hline $\mathrm{CD}(\mathrm{p}=0.05)$ & 106 & 81 & & 1.79 & 1.02 & & 8.47 & 5.45 & & NS & NS & & NS & NS & \\
\hline
\end{tabular}

All interactions: Non significant 
These findings are in accordance with the findings of Shiferaw et al., (2017), Balwinder and Gill (2010) and Kumar and Gill (2010).

\section{Clump weight}

Full rhizome treatment produced significantly higher clump weight plant ${ }^{-1}$ (1060 and 1010 g) over split rhizome treatment (835 and 922

g) during 2016 and 2017 respectively (Table 4). This is in accordance with the findings of Deshmukh et al., (2005), Ram pratap and Singh (2007), Balwinderkumar and Gill (2010) and Singh et al., (2013).

Among the different plant population densities tested, a plant population of 74,074 $\mathrm{ha}^{-1}$ recorded significantly higher clump weight plant ${ }^{-1}(1,165$ and $1,115 \mathrm{~g})$ over a plant stand of 1,48,148 ha ${ }^{-1}(821$ and $816 \mathrm{~g}$ ) and $98,765 \mathrm{ha}^{-1}$ (858 and $967 \mathrm{~g}$ ) during both the years of study 2016 and 2017.

Similar results were reported by Kumar and Gill, 2010. The higher rhizome weight in low plant population density might be due to better nourishment and more space for the clump to put up more weight.

\section{Girth and weight of mother rhizome}

The girth of mother rhizomes was 20.10 and $18.15 \mathrm{~cm}$ and weight of mother rhizomes was 82.33 and $90.02 \mathrm{~g}$ in full rhizome treatment which was significantly superior over split rhizome treatment which recorded a mean 18.14 and $16.80 \mathrm{~cm}$ of girth of mother rhizome and weight of mother rhizomes was 69.48 and $85.17 \mathrm{~g}$ during 2016 and 2017 respectively. A plant population density of $74,074 \mathrm{ha}^{-1}$ recorded $21.60 \mathrm{~cm}$ (mean girth of mother rhizomes) and $87.65 \mathrm{~g}$ (mean weight of mother rhizome plant $^{-1}$ ) which was higher than that recorded by a plant stand of 1,48,148 and 98,765 plant ha ${ }^{-1}$ (Table 4).

\section{Fresh rhizome yield per plot and yield per} hectare

The rhizome types (Full and split) deferred significantly for fresh rhizome yield per plot and yield per hectare of during both the years of study. Among the different rhizome types, full rhizome treatment recorded the maximum fresh rhizome yield per plot (36.15 and 28.57 $\mathrm{kg}$ ) and yield per hectare (24.10and $19.05 \mathrm{t}$ $\mathrm{ha}^{-1}$ ) during 2016 and 2017 respectively. Similar results were reported by Jage Singh et al., (2000), Alam et al., (2003), Zaman et al., (2005), Ram pratap and Singh (2007), Dhatt et al., (2008), Olojede et al., (2009), Balwinderkumar and Gill (2010), Manhas et al., (2010), Manhas et al., (2011), Padmadevi et al., (2012). Maximum rhizome yield in full rhizome treatment might be attributed to better crop growth in terms of higher plant height, more number of leaves per plant, which intercepted more photo-synthetically active radiation and resulted in higher yield of the crop. Difference in performance of full and split rhizomes can be attributed to sourcesink relationship, as full rhizome type constitutes a stronger sink than split rhizome.

There is a significant effect of plant population stand on fresh rhizome yield per plot and yield per hectare of turmeric. The maximum fresh rhizome yield per plot (33.93 and $26.47 \mathrm{~kg}$ ) and yield per hectare $(22.62$ and $17.65 \mathrm{t} \mathrm{ha}^{-1}$ ) was recorded by plant population stand of $1,48,148 \mathrm{ha}^{-1}$ treatment during 2016 and 2017. Similar results were reported by Choudhury et al., (2000), Singh et al., (2000), Bahadur et al., (2000), Carvalho et al., (2001), Islam et al., (2002), Filho et al., (2004), Silva et al., (2004), Kandiannan and Chandragir (2006), Pandey and Mishra (2009) and Kumar and Gill (2010). The possible reason for getting higher yields from closer spacing or higher plant population lies in the fact that larger number of plants was accommodated per hectare. Although the 
wider spacing or low population densities had resulted in higher number as well as weight of mother, primary, secondary and total rhizome yield per plant apparently due to less inter plant competition but higher plant population had contributed more towards yield. Pandey et al., (2011) and Bahadur et al., (2000) also reported similar results on total fresh rhizome yield in closer spacing compared to wider spacing.

It may be concluded from the above discussion that full rhizome is a better planting material than split rhizome and yield attributes namely number of mother rhizomes, primary fingers, secondary fingers, weight of mother rhizome and clump weight per plant increases with wider spacing. However, the total fresh rhizome yield showed reverse trend, which was maximum at closer spacing.

\section{References}

Aiyadural, S.G., 1966. A Review of Research on Spices and Cashewnut in India. Indian Council of Agricultural Research, India, pp: 228.

Alam, M.K., Islam, Z., Rouf, M.A., Alam, M.S. and Mondal, H.P. 2003. Response of Turmeric to planting material and mulching in the hilly region of Bangladesh. Pak. J. Biol. Sci., 6(1): 7-9.

Bahadur, M.M., Azad, A.K.M., Hakim, M.A., Hossain, M.M. and Sikdar, S.P. 2000. Effect of spacing and potassium levels on the growth and yield of turmeric var. Sinduri. Pak J Bio Sci., 3(4): 593-95.

Carvalho, C.M., Souza, R.J., Cecilio-Filho and De-Souza, R.J. 2001 Yield of turmeric (Curcuma longa L.) grown at different planting densities. Ciencia-eAgrotechnologia 25(2): 330-35. (Original not seen. Abst in CAB Abstracts.AN 20023075117, 2000-01).

Chandra, R., Decai, A.R. and Govind, S. 1997. Effect of foliar spray of $\mathrm{Mg}$ and planting materials on growth and yield of turmeric. J. Hill Res., 10(1): 1-4.

Choudhury, A.K., Hoque, A.F.M.E., Firoz, Z.A. and Quayyum, M.A. 2000 Performance of Turmeric-Legume intercropping system. Bangladesh $J$ Agri Res 25: 325-32.

Department of Horticulture, Government of Telangana, Advance Estimates 2016-17

Deshmukh, N.A., Gondane, S.U., Kadu, R.B., Chopde, N.K. and Shembekar, R.Z. 2005.Effect of planting material and varieties on growth, yield and quality of turmeric. Journal Soils and Crops. 15(2): 428-32.

Dhatt, A.S., Sidhu and Naveen Garg, 2008.Effect of planting material on plant growth, yield and rhizome size of turmeric. Indian Journal Horticulture. 65(2): 193-95.

Filho, A.B.C., Souza, R.J., Faquin, V. and Carvalho, C.M. 2004.Time and density of plantation on the turmeric production. Ciencia Rural 34: 1021-26.

Govinden, N., Wong, Y. and Cheong, K. 1995. Planting material and optimum planting rate for turmeric. RevueAgricoleetSucriere-de-lIle-Maurice 74(3): $1-8$.

Grima, H. and Kindie, T. 2008. The effects of seed rhizome size on the growth, yield and economic return of ginger (Zingiber officinale Rosc.). Asian Journal of Plant Sciences. 7(2): 213-17.

Hanamashetti, S.I., Narayanpur, V.B. and Hegde, N.K. 2002 Comparative performance of sixteen promising cultivars of turmeric (Curcuma longa L.) when finger and mother rhizomes were used as planting material. Proceedings of Placrosym. 15: 176-179.

Hari, H.P. Cohly, MaheshwaraRajeswaraRaoVijaya K. Kanji, BabuPatlolla, Anelle Taylor, Melanie T. Wilson, Michael F. Angel, and Suman K. Das. 2003 Effect of Turmeric, 
Turmerin and Curcumin on $\mathrm{Ca} 2+$, $\mathrm{Na} / \mathrm{K}+$ Atpases in Concanavalin AStimulated Human Blood Mononuclear Cells Int. J. Mol. Sci. 2003, 4, 34-44.

Holliday, R. (1960). Population and crop yield. Nature 186: 22-24.

Hossain, M.A., Ishimine, Y. Motomura, K. and Akamine, H. 2005 Effects of planting pattern and planting distance on growth and yield of turmeric (Curcuma longa L.).Plant prodSci8 (1): 95-105.

Indian Institute of Soil Science, 2009 IISS Publication, Two decades of Soil Research

Islam, F.,Karim, M.R., Shahjahan, M.,Hoque, M.O., Alam, M.R. and Hossain, M.A. 2002. Study on the effect of plant spacing on the production of turmeric at farmer's field. Asian J Plant Sci1: 61617.

Joe, A.M., Jeanine, M., Davis, N., Dwight, C., Ikhlas, K. and Bharathi, A. 2007. Influence of rhizome propagule size on yields and triterpene glycoside concentration of black cohosh Actaea racemosa L. syncimicifugaracemose (L.) Nuttal. Horticulture science. 42(1):61-64.

Kandiannan, K. and Chandragir, K.K. 2006 Influence of varieties, date of planting, spacing and nitrogen levels on growth, yield and quality of turmeric (Curcuma longa). Indian J Agri. Sci76: 432-34.

Kiran, M., Bibi, R., Jillani, M.S., Waseem, K., Ullah, G., Javeria, S. and Niamatullah, M. 2013 Effect of plant spacing on profitable yield of turmeric (Curcuma longa L.). Pak J Bio Sci65 (4): 486-91.

Kumar Balwinder and Gill, B.S. 2010 Growth, yield and quality of turmeric (Curcuma longa L.) as influenced by planting method, plant density and planting material. $J$ Spices and Aromatic Crops 19 (1and2): 42-49.
Kuttan, R., Bhanumathy, P., Nirmala, K. and George, M.C. 1985. Potential anticancer activity of turmeric (Curcuma longa L.). Cancer Lett., 29: 197-202.

Maia, N.B., Bovi, O.A., Duante, F.R., Soria, L.G. and de. Almeida, J.A.R. 1995. Influence of planting material on growth of turmeric. Bragantia, 54(1): 33-37.

Manhas, S.S., Gill, B.S. and Sushil Sharma. 2010. Effect of different planting material, planting dates and harvesting dates on economy of turmeric crop. Journal of Agricultural Physics. 10: 5052.

Manhas, S.S., Gill, B.S., Khajuria, V. and Kumar, S. 2011.Effect of planting material, mulch and farmyard manure on weed density, rhizome yield and quality of turmeric (Curcuma longa). Indian Journal of Agronomy. 56(4): 393-399.

Manjunathgoud, B., Venkatesh, J. and Bhagavantagoud, K.H. 2002. Studies on plant density and levels of NPK on growth, yield and quality of turmeric Cv. Bangalore Local. Mysore J. Agri. Sci., 36 (1): 31-35.

Meenakshi, N., Sulikeri, G.S. and Hegde, R.V. 2001. Effect of planting material, $\mathrm{P}$ and $\mathrm{K}$ nutrition on plant growth of turmeric. Karnataka J. Agric. Sci., 14(1): 194-196.

National Horticultural Board. 2014. http://www.nhb.gov.in/area-pro/Indian Horticulture 2014.pdf

Olojede, O.A., Nwokocha, C.C., Akinpelu, A.O. and Dalyop, T. 2009. Effect of Variety, Rhizome and Seed Bed Types on Yield of Turmeric (Curcuma longa L) under a Humid Tropical AgroEcology Advances in Biological Research 3 (1-2): 40-42

Padmadevi, K., JeevaJothi, L., Ponnuswami, V., Durgavathi, V. and Rijwana Parveen, I. 2012. Effect of different 
grades of rhizomes on growth and yield of turmeric (Curcuma longa L.).The Asian Journal of Horticulture. 7(2):46567.

Pandey, D.K. and Mishra, H.R. 2009. Effect of various doses of nitrogen and spacing on growth and yield of turmeric (Curcuma longa L.) Cv. Medukar. Veg Sci36 (1): 122-23.

Pandey, D.K., Mishra, D.P. and Mustafa, M. 2011. Response of various levels of nitrogen and plant spacing on yield and yield attributing characters of turmeric (Curcuma longa L.) at farmers field of Azamgarh, (Uttar Pradesh). Progressive Horticulture 43 (20): 320-22.

Philip, J. 1985. Effect of plant density on yield and yield component of turmeric .Indian cocoa Arecanut spices J 9: 9396.

Purseglove, J.W., Brown, E.G., Green, C.L. and Robbins, S.R.1981. Spices. 2nd Edn., Longman Group Limited, New York, pp: 537-539.

Ram,P. and Singh, T. 2007. Influence of types of rhizomes and plant geometry on growth, yield of turmeric (Curcuma longa L.). Progressive Agriculture. 7 (1/2):110-12.

Randhawa, K.S. and Mishra, K.A. 1974. Effect of sowing dates, seed size and spacing on the growth and yield of turmeric. Punjab Hort J 14: 53-55.

Risch. 1997. Spices: flavour chemistry and antioxidant properties. $\mathrm{X}+235 \mathrm{pp}$. Many ref. (Original not seen. Abst. In CAB Abstracts: AN 981404207, 2000).
Shiferaw Temteme, EssubalewGetachew, BehailuMekonnen and TesfayeShimber. 2017. Influence of Type of Planting Material, Plant Density and Method of Planting on the Yield and Quality of Turmeric (Curcuma domestica L.) at TepiSouthwestern Ethiopia Adv Crop Sci Tech 2017, 5:5

Silva, N.F. Sonnenberg, P.E. and Borges, J.D. 2004. Growth and production of turmeric as a result of mineral fertilizer and planting density. Hortic Bras 22: 61-65 (Original not seen. Abst. In CAB Abstracts: AN 20043062606, 2003-04).

Singh, J., Malik, Y.S., Nehra, B.K. and Partap, P.S., 2000.Effect of size of seed rhizomes and plant spacing on growth and yield of turmeric (Curcuma longa L.).Haryana J HortSci29: 258-60.

Srimal, R.C. 1997. Turmeric: a brief review of medicinal properties. Fitoterapia LXVIII, Pp. 483-493.

Yothasiri, A., Somwong, T., Tubngon, S., Kasirawat, T. and Amnuay, Y.1997. Effect of types and sizes of seed rhizomes on growth and yield of turmeric (Curcuma longa L). Kasetsart J. Natur. Sci., 31(1): 10-19.

Zaman, M. M., Nazrul, M. I., Hossain, M. A., Khan, M.A.H., Talukder, M.A.M. 2005. Growth and yield of turmeric as influenced by the planting and mulch material. International Journal of Sustainable Agricultural Technology. 1:35-39.

\section{How to cite this article:}

Preetham, Ashwini, Pavan and Ravi Kondle. 2018. Evaluation of Turmeric Variety Salem with Different Rhizome Types and Population Levels on Raised Beds. Int.J.Curr.Microbiol.App.Sci. 7(04): 3202-3211. doi: https://doi.org/10.20546/ijcmas.2018.704.363 